\title{
Effect of Mobile Credit on Operational Efficiency in Commercial Banks in Kenya
}

\author{
Koki F. Kinyanzui*, George Achoki, Peter Kiriri \\ Chandaria School of Business, United States International University Africa, Nairobi, Kenya \\ Email: ^kinyanzui@gmail.com
}

How to cite this paper: Kinyanzui, K.F., Achoki, G. and Kiriri, P. (2018) Effect of Mobile Credit on Operational Efficiency in Commercial Banks in Kenya. Open Journal of Business and Management, 6, 833-849. https://doi.org/10.4236/ojbm.2018.64062

Received: July 4, 2018

Accepted: August 28, 2018

Published: August 31, 2018

Copyright $\odot 2018$ by authors and Scientific Research Publishing Inc. This work is licensed under the Creative Commons Attribution International License (CC BY 4.0).

http://creativecommons.org/licenses/by/4.0/

\section{cc) (7) Open Access}

\begin{abstract}
This study sought to establish the effect of mobile credit on operational efficiency in commercial banks in Kenya. The study utilized primary as well as secondary data on access to mobile credit and its effects on the performance of the organization. A questionnaire was the primary data collection tool and composed of open ended and closed ended questions. Data collected was analyzed using multiple linear regression analysis at a $95 \%$ confidence interval. Analyzed data was presented using tables and figures for ease of interpretation. Operational efficiency is the goal of any manager in a customer service driven sector. Some of the strategies to achieve operational efficiency include managerial behavior change, promoting operational optimization and use of technology. Mobile credit introduction improved operational efficiency in commercial banks. Mobile credit introduction enhanced operational efficiency in loans collection, returns on shareholders. The operational efficiency performance indicators utilized in this study were: return on assets, earnings per share and proportion of non-performing loans. On the other hand, proportion of non-performing loans declined after the introduction of mobile credit indicating increased operational efficiency in debt collection. The introduction of mobile credit significantly enhanced organization efficiency as measured by metrics such by brand image building, ability to adapt to market changes and perceptions of reliability in the customer's mind. Mobile credit introduction improved operational efficiency in commercial banks. Mobile credit introduction enhanced operational efficiency in loans collection, returns on shareholders. Overall, it has been accepted that the use of technology is one of the major strategies used to enhance operational efficiency. The findings of this study propose that the use of mobile credit has enhanced debt collection efficiency and revenue generation efficiency.
\end{abstract}

\section{Keywords}

Mobile Credit, Operational Efficiency, Commercial Banks 


\section{Introduction}

Operational efficiency is the major goal for most organizations and companies. It is the goal of any manager in a customer service driven sector [1]. Some of the strategies to achieve operational efficiency include managerial behavior change, promoting operational optimization and use of technology [2]. Managerial behavior change involves the alteration of the behavior of the manager towards costs savings and reductions. On the other hand, operational optimization refers to the optimization of processes and systems in the companies to reduce costs [3].

Africa was the last continent to embrace the concept of credit which grew significantly in the 1950's when banks opened credit departments to provide loans to the elite and white colonialists [4]. In the Kenyan market, credit was primarily extended to wealthy individuals, as well as large companies, which meant that credit was not a widely known concept among the poor [4] [5]. In Africa, there has been immense growth in mobile credit. Most countries in Africa have mobile credit. In some markets such as Kenya, there has been phenomenal growth in mobile credit while in others the growth has been stifled [6]. Nevertheless, there has been overall growth in access to credit by the population as a result of mobile credit growth. Some of the countries with robust micro credit facilities and services include Uganda, Tanzania, Rwanda, Democratic Republic of Congo, South Africa, Namibia, Zimbabwe, Zambia, Madagascar, Nigeria, Ghana, Niger, Cameroon and Egypt.

Mobile money can be defined as the provision of banking services through the use of mobile devices such as mobile phones, credit cards and debit cards. It is an innovation that merges telecommunication service providers and financial service providers [7]. [8] defined mobile banking as the provision of electronic money accounts accessible through the mobile phone and other hand held gadgets. Undoubtedly, mobile banking has had a very positive effect on organization performance. Scholars such as [8] [9] [10] and the World Bank had identified various benefits of mobile banking such efficiency in the discharge of services banks, easy access to financial services, increased financial inclusion and improved profitability in the banking sector.

Around the world, mobile credit has grown in developing nations as opposed to the developed nations. In most developed nations, there are established financial credit systems such as credit cards and debit cards which users can use to access credit [11]. Consequently, the growth of mobile credit in this economy is at a slower pace than in most developing nations. In Africa, there has been an exponential growth in the mobile credit business, with most countries adopting mobile credit to enhance achievement of economic goals as well as enhance the access to credit [11].

The movement from the traditional banking to modern banking models led banks to establish strategies aimed at attracting more customers, as well as retaining the existing ones. In particular, the desire to reduce operational and ad- 
ministrative costs and competition were the major factors that influence banks to adopt mobile banking. However, [12] noted that the reduction of the operational and administrative costs was only achievable in the light of an increase of the customer's adoption. There is however, a general consensus among researchers and practitioners that technological advancements in the field of telecommunication and information had a major impact in revolutionizing the banking industry, especially in regards to the delivery of services.

According to [12], the continued increase of competition in the banking industry coerced most banks to innovate so as to survive; [13] note that such fierce competition was experienced at the global level. In order to survive in the turbulent market environment, banks used technology to enable them to employ strategies aimed at building customer satisfaction through the provision of better services and products while also minimizing the costs of operation.

In light of the success of other mobile banking services, such as the transfer of money between different accounts, checking balance, payment of utility bills, mobile airtime top ups, and performing other services other than the provision of credit, a majority of banks were motivated to explore other areas of banking services via the mobile services. Among the first banks that introduced the mobile credit is Commercial Bank of Africa (CBA); M-Shwari was introduced in 2012; the mobile credit service provided by CBA is known as M-Shwari where a consumer can access a loan that is payable within a month [14].

The establishment of such mobile credits opened up opportunities whose main requirement to access a loan is to deposit money on a consistent basis with the specific lender. The level of interest charged on loans is considered significantly lower- the interest charged on loans offered by M-Shwari is 7.5\%, compared to the traditional loan sharks, also known as shylocks, who had remained the only option among individuals working in the informal sectors since they lacked collateral or formal evidence of consistent income in order for banks to accept to extend credit to them (Al-Jabir, 2012). It is against this background that the study sought to establish the effects of effect of mobile credit on operational efficiency in commercial banks in Kenya.

\section{Statement of Problem}

Operation efficiency can be viewed as what occurs when the right combination of people, process and technology come together to boost the productivity and worth of any business operation, whereas driving down the cost of routine operations to a preferred level [15]. The result is that resources previously needed to manage operational tasks can be redirected to new, high value initiatives that bring additional capabilities to the organization. Despite extensive reforms in the financial sector in Sub Saharan Africa with a view of improving access to financial services to private agencies, financial depth in the sub-region has remained very low and not improving over the years. Commercial bank performance has been poor characterized by operational inefficiencies [16]. The application of 
new technologies has been proven as an effective way to reduce the costs of operation for the financial institutions. For instance, it will allow banks to reduce expenditures on physical structures. Thus, commercial banks consider the adoption of ICT as a means to increase the banks' efficiency and performance as well as quality of service.

Kenyan banks have taken big leaps in setting the bar high for themselves as pertains to emerging technology, improved facilities, redefined customer service and customer experience with most, if not all of the operational process fully automated. Access to financial services facilitators has realised numerous progressions since the developments in technology started taking root. Currently, customers of listed institutions that provide access to financial services have effective, quick and advantageous services, which are delivered through technological advancement, while a few question the capacity of making estimates of inventions ahead of time [17].

Around the world it was estimated that there were 255 mobile money services in 89 different countries that comprise of USSD, STK and IVR embedded applications [7]. It is estimated that over $70 \%$ of developing economies in the world have access to mobile money services [7]. However, mobile money is different from mobile credit. While mobile money refers to the entire eco system of mobile money transfer, savings and credit, mobile credit is constrained just to lending over mobile phones [18]. Since it is a relatively new concept in Kenya, mobile credit has led to an increase in the customer numbers and product delivery in Kenya. However, what effect does mobile credit have on operational efficiency in commercials banks?

Despite the undeniable importance of mobile credit in banking operations, the impact on operational efficiency is still misunderstood. Previous studies have produced mixed results with some concluding that technological innovations had least impact on bank operations and others indicating a significant contribution to bank operations. It is at the center of such mixed conclusions that creates and necessitates the need to carry out a study from a Kenyan context to establish the effect of mobile credit on operational efficiency in commercial banks in Kenya.

\section{General Objective and Scope of the Study}

The objective of the study was to examine the effect of mobile credit on operational efficiency of commercial banks in Kenya. This research study was carried out in Kenya using Commercial Banks with mobile credit and that were registered with the Central Bank of Kenya. There were a total of 43 banks in Kenya that were included in the study. The study was conducted in the Nairobi city where all the banks were located. Data was gathered online from the annual reports posted by commercial banks that offered mobile credit. The study analyzed financial information for commercial banks from the year 2010-2015; all banks had published their annual reports within this period. Data relating to customer 
satisfaction was collected using structured questionnaire in the survey period.

The researcher encountered various challenges which influenced the findings of this study. Data access and collection was one of the biggest challenges especially for primary data. Since managers in banks were busy while customers felt the study was non-significant to them this inhibited the response rates to the study. To overcome this challenge, the researcher undertook personal administration of the data collection tools. With the help of research assistants this enhanced a high response rate. Furthermore, the respondents were briefly informed on the scope, significance and importance of the study to enhance informed consent to the customers.

\section{Theoretical Review}

This study will be guided by the market power theory. The market power theory posits that external market forces are the source of market power for an organization. Market power is the ability of a firm or organization to change its prices for products and services and still maintain its market share [19]. The theory posits that when an organization has market power, any changes in the prices of goods and services will not result into losses of customers or market leadership. Market power is acquired from product differentiation and ease of access to services. According to [19] information communication innovations are sources of market power aimed at enhancing profit maximization. Consequently, the theory posits that any competitive advantage acquired through the use of technology to deliver services will not necessarily enhance market power for the bank. Consequently, any changes in the prices of the products will not result to losses in customers.

On the other hand, the efficiency structure theory posits that managerial and scale efficiency enhances concentration and higher levels of profitability. According to [20] a mix in the portfolio of products such as traditional brick and mortar based lending practices and mobile lending will lead to stability in the banks, efficiency and profitability. Consequently, the theory posits that banks that adopt mobile credit are more stable and perform better due to higher levels of concentration.

The efficiency structure theory is the most relevant theory in this study. In this study, the theory posits that the use of a mix approach to traditional lending practices and mobile credit are key sustainable and profitable companies in Kenya. Despite the apparent benefits of mobile credit, it is key for the process of mobile financial intermediation to be backed by traditional financial intermediation processes to enhance risk reduction, profit maximization and enhance efficiency in the organizations.

Furthermore, the market power and efficiency theory is applicable in this study as it proposes that the performance of commercial banks in Kenya is a result of internal and external factors. Consequently, the performance change in the banks due to introduction of mobile credit and lending is influenced by in- 
ternal and external factors. The internal factors that influence the contribution of mobile lending to bank performance include: the bank size, the total capital outlay or capitalization of the company, levels of managerial efficiency and the risk management frameworks inherent in the banks operational systems [19]. On the other hand, external factors such as interest rate movements, price floors and ceilings, government regulations, economic growth and bank ownership are factors that influence the success of mobile credit and thus the contribution of mobile credit to the organization performance.

\section{Empirical Review}

Operational efficiency is the major goal for most organizations and companies. According to [1] operational efficiency is the goal of any manager in a customer service driven sector. Some of the strategies to achieve operational efficiency include managerial behavior change, promoting operational optimization and use of technology [2]. Managerial behavior change involves the alteration of the behavior of the manager towards costs savings and reductions. On the other hand, operational optimization refers to the optimization of processes and systems in the companies to reduce costs [3].

Use of technology is one of the major strategies used to enhance operational efficiency. According to [7], there are various strategies through organizations can reduce the customer service related costs and increase customer satisfaction at the same time. One of the strategies that companies use to reduce customer service costs is the use of e-service and technology to enhance self-service [7]. [21] found similar findings in their study on technology efficiency. They noted that technology use and efficiency in the use of technology was a very important tool in the reduction of operating costs within businesses in Ivory Coast. Further, [22] noted that organization must use technology, update their technology systems for them to have operational efficiency, reduce costs and acquire a competitive edge.

Customers prefer the use of automated services such as Automated teller Machines, Smart banks and mini banks [15]. According to [17], the banking community has utilized the use of virtual banks and online presence to push the customer service costs down and enhance customer efficiency. Some of the virtual banks include interactive banking systems that predict the needs of the customer and provides information to the customers beforehand. According to [23], " 80 percent of the time customers use technology in accessing banking services, they confirm that they are satisfied with the explanation given by the automated system. If they aren't, they are immediately routed to an agent who has a complete transcript of the conversation and can provide the next level of service." Another advantage identified by [23] was that technology reduced the time spent by customer in resolving issues and complaints while customer service employees enjoy from reduced calls.

In a study on mobile banking in Malaysia, [13] analyzed the effect of mobile 
banking on economic growth and expansion through a link adoption, use and effect model. The study using a data set over 100,000 individuals found that the use of mobile banking offered a cost effective strategy for stimulating savings, transfer of money and enhancing financial inclusion in the country. According to the study, mobile banking and mobile payment systems could prove to be disruptive innovations that enhance operational efficiencies in the banking sector as well as altering the delivery and consumption of financial products around the world. Mobile banking and payment systems provide for cheap, cost effective systems to transfer money from one place to another, bring more individuals into the banking and financial systems and increase the consumption and use of financial services without the subsequent increase in operational costs [13].

[16] noted that most banks in the United Kingdom (UK) had adopted the use of e-commerce in the delivery of services to customers. Further, he noted that banks were planning to introduce telephone banking in the United Kingdom is a strategy to reduce customer service costs. However, this was met with little excitement from the customers [16]. [10] argued that the growth in use of internet to provide banking services was driven by the need to reduce customer service costs on the part of the bank and increased acceptance of online banking buy customers on the other. This was supported by [15] who noted that banks were finding it easier and cheaper to meet the needs of their customers online rather than in banking halls. Furthermore, banks had to respond to competitive forces in the market especially in the deployment of technology in service delivery.

In a survey of Nigerian Banks, [14] identified a positive relationship between efficiency and productivity of the banking sector. According to [14] technology in the banking sector led to a reduction in the operational costs and marketing costs for the bank. As a result, banks incurred lower costs is service delivery and production of services. Banks enjoy the efficiencies of technology since they do not have to spend a lot of funds in the development and refurbishment of branches as well as the employment of a large number of employees to serve customers in the new banks. Consequently, banks that leverage on technology enjoy lower levels of operational costs or costs to serve customers.

Ho and Mallick [6] noted that there exist a positive relationship between information technology use and bank performance. The use of information technology in the banking sector led to a reduction in the overall operational costs of the bank i.e. Cost efficiency. [6] argued that, "IT can reduce banks' operational costs (the cost advantage). For example, internet helps banks to conduct standardized, low value-added transactions (e.g. bill payments, balance inquiries, account transfer) through the online channel, while focusing their resources into specialized, high-value added transactions (e.g. small business lending, personal trust services, investment banking) through branches."

[7], in the study the impact of ICT on productivity. the moderating role of worker quality and quality strategy, noted that the adoption of technology in the delivery of services and products improved the overall operational efficiency 
measured in terms of costs necessary to produce and distribute the products. According to [7], firms that invested in technology and innovation experienced low levels of operational and production costs which could be attributed to the cost savings and efficiency of technology. This is similar to the findings of Gagnon and Dragon who noted that the use of technology in the production of goods and services reduced the overall expenses and costs incurred in the delivery and production of services.

[19] in a study on Kenyan micro finance banks offering mobile banking investigated the effect of mobile banking on transaction costs. [19] found that the use of mobile banking products and services by microfinance banks enhanced operational efficiency by reducing the overall transaction costs of the microfinance banks. In addition, [19] noted that customer service costs associated with offering services to customers at brick and mortar branches were reduced through the use of mobile banking. Nevertheless, the study by [19] found that the overall banking costs of microfinance banks did not reduce due to the small customer base of micro finance institutions. However, this may not be applicable to commercial banks because they have a large customer base.

[12] analyzed the effect of mobile money on non-performing loans of commercial banks in Kenya which is a key measure of operational efficiency. The non-performing loans indicate challenges of debt collection or wrong debt collection strategies for commercial banks in Kenya. Using a multiple regression analysis approach, the study found that the use of mobile phone banking increased the levels of non-performing loans in commercial banks. This means that the use of mobile phones in delivery of banking services and products increased the levels of non-performing loans in commercial banks. This was attributed to the ease in accessing the loans despite the lack of due diligence such as the employment details or status of the borrowers. According to [12] commercial banks mostly relied on the credit report of customers offered by the credit reference bureaus to make a lend decision. Since credit report and information sharing was still very weak in Kenya, this information was not adequate to make lending. Consequently, the levels of non-performing loans in Kenya increased from the adoption of mobile banking [12].

The findings of [12] contradict those of [4] who in studies conducted in South Africa and USA respectively found that the provision of unsecured lending of small amounts to lower income groups offered referred to high risk loans was more beneficial to the commercial banks than low risk secured loans. Mobile phone based loans are small and micro in nature and are unsecured and thus fall in this category. According to [8], students and low income individuals have a high compliance rate to repayment of debts than rich individuals taking unsecured loans.

The negative effect of mobile banking is grounded in the information theory. According to the information theory, the provision of credit facilities must be based on customer screening through credit assessment platforms [6]. Commer- 
cial banks must collect reliable data on the credit customers to make a comprehensive lending decision. This information must include qualitative and quantitative data. As noted by [9] the lack of reliable information is the major challenge faced by commercial banks in forming lending decisions. Mobile credit lending complicates this process since individuals purchasing a mobile SIM card can access loans from the providers without comprehensive information about the customer. This reduces the organization efficiency levels and leads to increased non-performing loans in commercial banks. As noted by [12] the lack of data collection processes and reliable data on customers increases the overall processing costs for commercial banks and leads to the making of subjective lending decisions that are prone to bias.

\section{Variables and Model}

This study was based on the variables: Operational efficiency as the dependent variable while the independent variable was mobile credit. In this relationship, operational efficiency referring to the overall costs of operational and cost cutting strategies in the organization influence the relationship between financial performance and bank performance. For example, if higher revenues were generated by the mobile credit but the operational expenses were still high, this affected the relationship between financial performance and bank performance (Figure 1).

\section{Research Methodology}

This study is anchored on the positivism paradigm because it seeks to objectively establish facts by empirically establishing relationships among variables. Also, it is based on the theory from which hypothesis are drawn. The hypotheses will be tested, accepted or rejected leading to what could lead to further research. Positivism seeks to unveil the fact or causes of social phenomena. Positivism approach is theory testing as opposed to epistemology which is theory building. This study will therefore adopt the positivist approach.

This study used an explanatory research design. In an explanatory research design, the researcher seeks to establish a causal relationship between variables. It involves the analysis of a situation or a problem in order to establish relationships between variables [10]. This study sought to analyze the relationship between mobile credit provision and organization performance in commercial banks in Kenya. A cross sectional descriptive case study was employed in this case study because the unit of analysis was narrowed down to only banks with

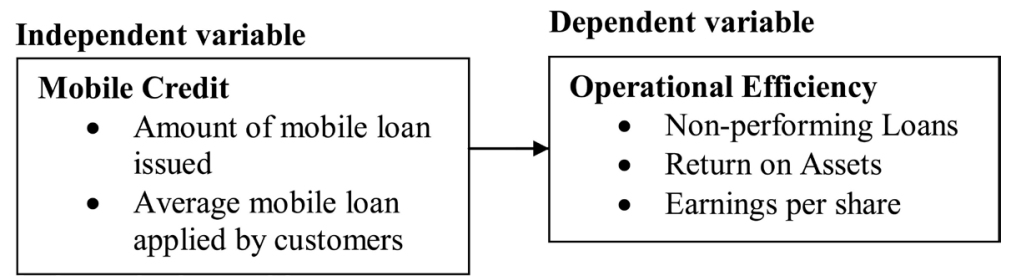

Figure 1. Conceptual framework. 
mobile credit which were five and therefore a census was appropriate. This was also to inform who, how and what about the mobile credit in commercial banks in Kenya and as a onetime event.

The customers of commercial banks in Kenya formed the population of the study. According to the Central Bank of Kenya, there were over 31 million accounts in Kenya including individual and corporate accounts [20]. The thirty-one million accounts formed the population of the study. Since the population of this study was not very large, a census survey was conducted. The distribution of the sample size was as shown in Table 1.

For each of the 5 banks selected, data for the period 2010-2015 on the financial performance was analyzed to investigate the effect of introduction of mobile credit on organization performance. Data was collected on: return on assets, $\mathrm{Li}$ quidity ratio and the total assets. To reduce the sampling error a total of 500 customers representing 100 customers per bank offering mobile credit services were included in the study. A total of 100 customers for each of the banks were randomly selected for inclusion in the study. The sample size of 100 was considered large enough to generalize findings due to homogeneity of the product and services offered.

The study made use of both primary and secondary data. Primary data was collected using a structured questionnaire whereas secondary data was obtained from the Audited Financial statements of the Banks, those deposited at the Nairobi Securities Exchange and financial performance data from Central Bank of Kenya annual banking survey reports. The data collected was cleaned, coded and organized systematically in a manner that enabled an effective analysis of the data based on the SPSS (Statistical Package for Social Sciences) vs. 21. The quantitative analysis was analyzed based on the descriptive statistics including the measurement of central tendency that generated appropriate percentages, frequencies, mode, and median and mean. The regression model was tested to depict the relationship between the dependent and independent variables. The significance of each independent variable was also being tested. Fischer distribution test called F-test was applied. F-test was used to test the significance of the overall model at a 95 percent confidence level.

In order to test for normality, histograms and Q-Q plots; skewness and kurtosis; Shapiro-Wilk test will be used. To test for multicollinearity, tolerance and

Table 1. Sample size distribution.

\begin{tabular}{ccccc}
\hline Description & $\begin{array}{c}\text { With Mobile Banking but } \\
\text { without Mobile Credit }\end{array}$ & $\begin{array}{c}\text { With Mobile Banking and } \\
\text { Mobile Credit }\end{array}$ & Total & Percent \\
\hline Tier I Banks & 3 & 3 & 6 & $27 \%$ \\
Tier II Banks & 9 & 2 & 11 & $50 \%$ \\
Tier III Banks & 5 & 0 & 5 & $23 \%$ \\
Total & $\mathbf{1 7}$ & $\mathbf{5}$ & $\mathbf{2 2}$ & $\mathbf{1 0 0}$ \\
\hline
\end{tabular}

Source: Central Bank of Kenya (2015). 
Variance Inflation Factor (VIF) will be used where tolerance of less than 1 indicates lack of multicollinearity, Variance Inflation Factor (VIF) greater or equal to 5 shows multicollinearity is a problem, over 15 indicates possible multicollinearity problems whereas over 30 indicates serious multicollinearity problems. Both graphical and Levene's test for homogeneity of variance will be used to test for homogeneity. If the Levene's statistic is significant at the 0.05 levels, the null hypothesis that the groups have no equal variances will be rejected.

\section{Results and Discussions}

\subsection{Response Rate}

The study targeted 10 managers and 500 customers, however, the researcher received response from 8 the managers and 467 customers, representing a response rate of $80.0 \%$, and $93.4 \%$ respectively. Therefore, this study's response rate is considered very good for survey research as recommended by [24] who proposes a score of $80 \%-95 \%$ as good response rate, whereas [25] suggest a $50 \%$ response rate is adequate, $60 \%$ good and above $70 \%$ very good.

\subsection{Mobile Credit and Operational Efficiency}

The statements according to the managers depicting the manifestations of mobile credit and how it relate to operational efficiency of commercial banks offering mobile credit were evaluated and presented in Table 2.

The overall mean score of how mobile credit manifestations influence operational efficiency is 3.8318 and standard deviation of 0.87506 . This is a high mean score implying that the managers were in agreement that mobile credit influences operational efficiency of commercial banks offering mobile credit. The statement with the highest mean score was that there has been a reduced number

Table 2. Mobile credit and operational efficiency.

\begin{tabular}{|c|c|c|c|}
\hline & $\mathrm{N}$ & Mean & Std. Deviation \\
\hline Mobile credit services have reduced the proportion of non-performing loans in the commercial bank & 8 & 3.2273 & 1.19251 \\
\hline Mobile credit services introduction has led to reduction in operating expenses of the commercial bank & 8 & 3.4545 & 1.14340 \\
\hline Mobile credit services introduction has led to reduced costs to serve costumers & 8 & 4.0000 & 0.69007 \\
\hline Mobile credit services introduction has led to increased market penetration by the commercial banks & 8 & 3.5909 & 1.14056 \\
\hline Mobile credit services introduction has reduced the time customers use to solve issues and complaints & 8 & 4.0909 & 0.61016 \\
\hline There has been a reduced number of customer service calls from the introduction of mobile credit services & 8 & 4.1818 & 0.79501 \\
\hline The introduction of mobile credit services has stimulated product innovation at the bank & 8 & 3.9545 & 0.89853 \\
\hline The introduction of mobile phone loans has enhanced the provision of bundled products to customers & 8 & 3.8182 & 0.66450 \\
\hline Mobile phone loans introduction has enhanced debt collection efficiency at the bank & 8 & 4.0000 & 0.92582 \\
\hline $\begin{array}{l}\text { Mobile phone loans introduction in the commercial bank has reduced the customer information collection } \\
\text { costs for the bank }\end{array}$ & 8 & 4.0000 & 0.69007 \\
\hline Average Mean Score & 8 & 3.8318 & 0.87506 \\
\hline
\end{tabular}

Source: Primary Data (2018). 
of customer service calls from the introduction of mobile credit services $($ Mean $=$ $4.1818, \mathrm{SD}=0.79501)$. Other statements include: Mobile credit services introduction has reduced the time customers use to solve issues and complaints (Mean $=4.0909, \mathrm{SD}=0.6106)$, Mobile credit services introduction has led to reduced costs to serve costumers (Mean $=4.0000, \mathrm{SD}=0.69007$ ), Mobile phone loans introduction in the commercial bank has reduced the customer information collection costs for the bank (Mean $=4.0000, \mathrm{SD}=0.69007$ ), Mobile phone loans introduction has enhanced debt collection efficiency at the bank (Mean = 4.0000, $\mathrm{SD}=0.92582$ ), The introduction of mobile credit services has stimulated product innovation at the bank (Mean $=3.9545, \mathrm{SD}=0.89853$ ), The introduction of mobile phone loans has enhanced the provision of bundled products to customers $($ Mean $=3.8182, \mathrm{SD}=0.66450)$, Mobile credit services introduction has led to increased market penetration by the commercial banks (Mean = $3.5909, \mathrm{SD}=1.14056)$ and Mobile credit services introduction has led to reduction in operating expenses of the commercial bank (Mean $=3.4545, \mathrm{SD}=$ 1.14340). The statement with the lowest mean score was that mobile credit services have reduced the proportion of non-performing loans in the commercial bank (Mean $=3.2273, \mathrm{SD}=1.1925)$. This implies that operational efficiency is influenced by the introduction of mobile credit services.

Though mobile phones make communication easier, resulting in economic growth, they can also be useful for things other than simple communication. Such innovation is mobile money: using mobile phones to electronically store currency and pay for goods and services via short message service (SMS) as well as access to credit services from banks, an individual can easily check balance, account statements, save, credit statements and other wide variety services offered in mobile banking. An individual is able to receive notifications on loan payment dates and amount using the same device. With this, one is able to make prompt payment other than visiting physical banks and queuing in the banking halls. With this invention, it has reduced the rate of calls a customer receives from the bank concerning loan repayment.

The results of these study is synonym as Donner and Tellez (2008) study that analyzed the effect of mobile banking on economic growth and expansion through a link adoption, use and effect model. The study using a data set over 100,000 individuals found that the use of mobile banking offered a cost effective strategy for stimulating savings, transfer of money and enhancing financial inclusion in the country. According to the study, mobile banking and mobile payment systems could prove to be disruptive innovations that enhance operational efficiencies in the banking sector as well as altering the delivery and consumption of financial products around the world. Mobile banking and payment systems provide for cheap, cost effective systems to transfer money from one place to another, bring more individuals into the banking and financial systems and increase the consumption and use of financial services without the subsequent increase in operational costs. 
The innovation of mobile money services in Kenya been a blessing to the banking sector as it has eased in inconvenience one cost by physical transactions. Because mobile money is a cheaper, safer, and more convenient way to transfer funds, and reduces the costs associated with saving and lending, consumers in developing countries are recognizing its benefits. Banking has thus been moved from traditional brick and mortar to virtual existence where money is transferred from the comfort of customers' homes. Customer can transfer money, meant from loan repayments, from their mobile accounts to banks. This has helped reduce nonperforming loans. Besides, mobile money has impacted the economic growth through facilitating various transactions at relatively cheap costs, ease of accessibility and operation.

Use of technology is one of the major strategies used to enhance operational efficiency. According to [17], there are various strategies through organizations can reduce the customer service related costs and increase customer satisfaction at the same time. One of the strategies that companies use to reduce customer service costs is the use of e-service and technology to enhance self-service [13]. [16] found similar findings in their study on technology efficiency. They noted that technology use and efficiency in the use of technology was a very important tool in the reduction of operating costs within businesses in Ivory Coast. Further, [26] noted that organization must use technology, update their technology systems for them to have operational efficiency, reduce costs and acquire a competitive edge. These earlier studies concurs with results from this study that technology adopted in banking through mobile credit has a reduced number of customer service calls from the introduction of mobile credit services as well as reduced the time customers use to solve issues and complaints.

Additionally, Mobile credit introduction in the commercial bank has reduced the customer information collection costs for the bank. Since customers are able to check for loan payments dates and amounts easily using their mobile phones, they are able to make payments within the required period using the same devices at their convenience. Through mobile services, customers do not have to go through hustles of queuing in the banking halls to make their loan payments. On the other hand, mobile credit has created an easy follow up for the commercial banks on their customers. Commercial banks can follow up on the payments of via SMS's and few calls and not necessarily availing themselves at their customers' homes.

\section{Hypothesis Testing}

The study established the relationship between mobile credit and operational efficiency through the hypothesis that $\mathrm{H}_{1}$ : There was a positive significant relationship between mobile credit and operational efficiency in commercial banks in Kenya. The composite index was computed for both mobile credit attributes and operational efficiency and the hypothesis tested through multiple regression analysis. The results were as presented in Table 3. 
Table 3. Regression Results of mobile credit and operational efficiency. (a) Model Summary; (b) ANOVA ${ }^{\text {a }}$; (c) Combined coefficients.

(a)

\begin{tabular}{ccccc}
\hline Model & $\mathrm{R}$ & R Square & Adjusted R Square & Std. Error of the Estimate \\
\hline Mobile credit & $0.209^{\mathrm{a}}$ & 0.044 & -0.022 & 0.28703 \\
\hline
\end{tabular}

a. Predictors: (Constant), Mobile credit.

(b)

\begin{tabular}{|c|c|c|c|c|c|c|}
\hline \multicolumn{2}{|c|}{ Model } & Sum of Squares & Df & Mean Square & $\mathrm{F}$ & Sig. \\
\hline \multirow{3}{*}{ Mobile credit } & Regression & 0.001 & 1 & 0.001 & 0.007 & $0.936^{\mathrm{a}}$ \\
\hline & Residual & 3.790 & 7 & 0.082 & & \\
\hline & Total & 3.790 & 8 & & & \\
\hline
\end{tabular}

a. Dependent Variable: Operational efficiency; b. Predictors: (Constant), Mobile credit.

(c)

\begin{tabular}{|c|c|c|c|c|c|}
\hline \multirow{2}{*}{ Model } & \multicolumn{2}{|c|}{ Unstandardized Coefficients } & \multirow{2}{*}{$\begin{array}{c}\text { Standardized Coefficients } \\
\text { Beta }\end{array}$} & \multirow{2}{*}{$\mathrm{t}$} & \multirow{2}{*}{ Sig. } \\
\hline & B & Std. Error & & & \\
\hline (Constant) & 3.426 & 0.238 & & 14.379 & 0.000 \\
\hline Mobile credit & -0.005 & 0.064 & -0.012 & -0.081 & 0.936 \\
\hline
\end{tabular}

a. Dependent Variable: Operational efficiency (NPL, ROA, EPS). Source: Primary Data (2018).

The results show $\mathrm{R}=0.209$ and a beta co-efficient of -0.005 implying that there exists a weak and inverse relationship between mobile credit and operational efficiency. Mobile credit have a weak influence on operational efficiency shown by the coefficient of determination $\mathrm{R}^{2}=0.044$ which indicates that mobile credit influence operational efficiency by only $4.4 \%$ with other factors not considered in the model influencing $95.6 \%$. The relationship between mobile credit and operational efficiency is statistically insignificant since p-value $>0.05(\mathrm{P}=$ 0.936 ) at $95 \%$ confidence level. The $\mathrm{F}$ value is 0.007 and $\mathrm{p}=0.936>0.05$ depicting an insignificant model. Results of the coefficients show that a unit increases in mobile credit will cause a -0.005 decrease in operational efficiency. This implies that as mobile credit increase, its ability to operate efficiently reduces, suggesting that mobile credit alone is not a good predictor of operational efficiency. The findings, consequently, were not sufficient to support the hypothesis that mobile credit have an influence on operational efficiency, thus the hypothesis $\left(\mathrm{H}_{2}\right)$ was rejected.

The regression equation can thus be written as follows:

$$
\mathrm{Y}=3.426+-0.005 \mathrm{MC}
$$

where $\mathrm{Y}=$ Operational efficiency, $\mathrm{MC}=$ Mobile credit.

\section{Conclusions and Recommendations}

Overall, mobile credit introduction improved operational efficiency in commercial banks. Mobile credit introduction enhanced operational efficiency in loans 
collection, returns on shareholders. Nevertheless, returns on resources employed by commercial banks reduced as a result of introduction of mobile credit introduction. Since loans secured by customers through mobile credit are less, it then becomes easier for them to repay them compared to huge loans that require big securities and cannot be accessed via mobile.

When traditional collection processes have faltered, the techniques and practices adopted as a part of the modern collection management systems go a long way to address several pain points that were encountered in the earlier systems. With improved technology adopted in the banking industry in Kenya, debt collection has been simpler since it has enabled easier tracking of the debtor. The study concludes that mobile technology is helpful in the area of debt collection. Almost everyone has a mobile device these days, especially those in the business world. This makes it much easier to get in touch with people since everyone usually keeps their mobile phone close, thereby making it easier to get notifications and updates of loan repayment dates and act accordingly. Further through mobile credit, customer statements and payments are sent via comfortable mediums as SMS, thereby circumventing a trip to the bank. Therefore, based on the findings, the study concludes that mobile credit has increased operational efficiency of commercial banks in Kenya.

Mobile credit enables for analytics. Therefore, software can now automatically flag and score felonies based on factors, such as amount due, aging, percentage outstanding and credit limit. This comes in handy to aid with a more well-rounded and efficient segregation of customers. Once this segregation is done, the database can also be used to personalize collection strategy for each customer or a category by sending friendly reminders to facilitate loan repayment. The study hence concludes that mobile credit has reduced the occurrence of nonperforming loans, thereby making commercial banks thrive in business.

To further increase efficiency in banks, there is need for pumping more resources and investment on technologies to ensure efficiency in serving customer and overall satisfaction of customers. Customer satisfaction should be kept in mind as banks upgrade the existing systems to fully adopt mobile credit. Further banks should re-engineer and modify their systems in order to enhance their efficiency in service as well as the use of customer relationship models. In addition, the mobile credit interface should be made more user-friendly in terms of adopting the national languages, English and Kiswahili so that it is accessible to majority. There is also the need to improve the services by adding more products offered to the service. This will create a sustainability service and ensure efficiency in operation by the users as well as the banks.

\section{Conflicts of Interest}

The authors declare no conflicts of interest regarding the publication of this paper.

\section{References}

[1] Radić, N., Fiordelisi, F. and Girardone, C. (2012) Efficiency and Risk-Taking in 
Pre-Crisis Investment Banks. Journal of Financial Services Research, 41, 81-101. https://doi.org/10.1007/s10693-011-0111-1

[2] Rutto, C. (2014) The Effect of Cost to Serve on Financial Performance: A Case of Standard Chartered Bank of Kenya. Unpublished Global Executive Masters Research Report, United States International University, 20-30.

[3] Al-Jabir (2012) Mobile Banking Adoption: Application of Diffusion of Innovation Theory. Journal of Electronic Commerce Research, 13, 43-82.

[4] Chijoriga, M.M. (1997) An Application of Credit Scoring and Financial Distress Prediction Model to Commercial Bank Lending: The Case of Tanzania. Ph.D Dissertation, Witrtschaftsuniversitat Wien, Vienna, 10-23.

[5] Dash, M. and Kabra, G. (2010) The Determinants of Non-Performing Assets in Indian Commercial Bank: An Econometric Study. Middle Eastern Finance and Economics, No. 7, 94-106.

[6] Binnet, J. and Tellez, A.C. (2008) Mobile Banking and Economic Development: Linking Adoption, Impact, and Use. Asian Journal of Communication, 18, 318-322. https://doi.org/10.1080/01292980802344190

[7] Grabarek, B. (2012) Using Technology to Reduce Customer Service Costs and Improve Satisfaction. Pay before Resource, 6, 161-173.

[8] Anyasi, F.I. and Otubu, P.A. (2009) Mobile Phone Technology in Banking System: It's Economic Effect. Research Journal of Information Technology, 1, 1-5.

[9] Sohail, M. and Shanmugham, B. (2003) E-Banking and Customer Preferences in Malaysia: An Empirical Investigation. Information Sciences, 150, 207-217. https://doi.org/10.1016/S0020-0255(02)00378-X

[10] Tiwari, R., Buse, S. and Herstatt, C. (2015) Mobile Banking as Business Strategy: Impact of Mobile Technologies on Customer Behaviour and Its Implications for Banks. Technology Management for the Global Future, Proceedings of PICMET '06, 8-13 July 2006, Istanbul, 1935-1946.

[11] Ching, M.C., Chuan, A.T., Sim, J.J., Kam, H. and Tan, B. (2011) Factors Affecting Malaysian Mobile Banking Adoption: An Empirical Analysis. International Journal of Network and Mobile Technologies, 2, 161-173.

[12] World Bank (2010) Information and Communications for Development 2010: Maximizing Mobile. World Bank, Washington DC.

[13] Dhillon, V.S. (2012) Impact of Operational Efficiency on Overall Profitability-A Case Study of GIPCL. Working Paper No.136/2012.

[14] Munaye, H. (2009) The Application of Mobile Banking as a Strategic Response by Equity Bank Kenya Limited to the Challenge in the External Environment. Unpublished MBA Thesis, University of Nairobi, Nairobi, 25-36.

[15] Donner, J. and Tellez, A.C. (2008) Mobile Banking and Economic Development: Linking Adoption, Impact, and Use. Asian Journal of Communication, 18, 318-322. https://doi.org/10.1080/01292980802344190

[16] Oluwagbemi, O., Abah, J. and Achimugu, P. (2011) The Impact of Information Technology in Nigeria's Banking Industry. Journal of Computer Science and Engineering, 7, 25-36.

[17] Fister, S. (2016) Banking on Mobile. PM Network, 30, 28-37.

[18] Thomond, P. and Lettice, F. (2002) Disruptive Innovation Explored. 9th IPSE International Conference on Concurrent Engineering. Research and Applications, Cranfield, 27-31 July 2002.

[19] Ogeni, O., Abah, J. and Achimugu, P. (2011) The Impact of Information Technolo- 
gy in Nigeria’s Banking Industry. Journal of Computer Science and Engineering, 7, 25-36.

[20] Ho, S. and Mallick, S. (2006) The Impact of Information Technology on the Banking Industry: Theory and Empirics. National Chengchi University, 15-23.

[21] Kigen, K.P. (2010) The Impact of Mobile Banking on Transaction Costs of Microfinance Institutions. Unpublished MBA Thesis, University of Nairobi, Nairobi, 25-36.

[22] Gaitho, M. (2010) A Survey of Credit Risk Management Practices by SACCOs in Nairobi. Unpublished MBA Project, University of Nairobi, Nairobi, 15-25.

[23] Gargallo Castel, A. and Galve Gorriz, C. (2012) The Impact of ICT on Productivity: The Moderating Role of Worker Quality and Quality Strategy. University of Zaragoza, Zaragoza. https://doi.org/10.5772/37291

[24] Punch, K. (2003) Survey Research: The Basics. Sage, Thousand Oaks. https://doi.org/10.4135/9781849209984

[25] Mugenda, D.M. and Mugenda, D. (1999) Research Methods; Quantitative and Qualitative Research.

[26] Githinji, M.W. (2010) The Relationship between Credit Scoring Practices by Commercial Banks and Access to Credit by SMEs in Kenya. Unpublished MBA Project, University of Nairobi, Nairobi, 23-25. 